${ }^{1}$ Dr. Sc., Prof., Head of the Computer Science Department of Sumy State University, Sumy, Ukraine ${ }^{2} \mathrm{PhD}$, Head of the Computer Science Department of the Sumy State University, Sumy, Ukraine ${ }^{3} \mathrm{PhD}$, Associate Professor, Associate Professor of Computer Science Department of the Sumy State University, Sumy, Ukraine ${ }^{4}$ Postgraduate student of the Department of Computer Science of Sumy State University, Sumy, Ukraine

\title{
OPTIMIZATION OF PARAMETERS OF MACHINE LEARNING OF THE SYSTEM OF FUNCTIONAL DIAGNOSTICS OF THE ELECTRIC DRIVE OF A SHAFT LIFTING MACHINE
}

\footnotetext{
Relevance. The actual task of increasing the functional efficiency of machine learning of the system of functional diagnosis of the electric drive of a hoisting mine machine is solved.

The specific objective of this study was to develop a method for the information synthesis of a learning system for the functional diagnosis of the electric drive of a hoisting mine machine, which allows increasing the reliability and efficiency of diagnostic solutions in accordance with the decisive rules built in the process of machine learning.

Method. The method of information-extreme machine learning of the system of functional diagnosis of the electric drive of a minehoisting machine is proposed, based on the maximization of the information capacity of the system in the process of its training. Based on the computer-generated optimal learning parameters of the hyperspherical containers of the recognition classes, within the framework of the geometric approach, decisive rules that are practically invariant to the spatiality of the space of diagnostic features are constructed. In addition, increasing the efficiency of machine learning systems is achieved by parallel-sequential optimization of control tolerances for diagnostic features. In this case, the quasi-optimal control tolerances for diagnostic tests obtained during parallel optimization are used as start-ups for their sequential optimization. As a criterion for optimizing the parameters of machine learning, the modified information measure of Kulbak is used, which is a functional of the accuracy characteristics of diagnostic solutions.

Results. The algorithmic and software for machine learning of the system for functional diagnosis of the electric drive of a mine hoisting machine has been developed, which makes it possible to build decisive rules for the adoption of highly reliable diagnostic solutions when the system is in operation.

Conclusions. The results of physical modeling confirm the operability of the proposed method of machine learning and the developed software of the functional diagnosis system of the electric drive of a hoisting mine machine, which allows them to be recommended for solving practical problems of diagnosing and automatic control of traction machines.

Keywords: informationally-extreme intellectual technology, functional control, learning matrix, machine learning, information criterion, electric drive, mine hoisting machine.
}

\section{NOMENCLATURE}

IEI - informationally-extreme intellectual technology;

HMM - hoisting mine machine;

$M$ - number of recognition classes;

$N$ - number of diagnostic features;

$n$ - number of vectors-implementation classes recognition;

$x_{m}$ - binary averaging vector-implementation, which vertex determines the geometric center of the hyperspherical container of the recognition class $X_{m}^{o}$;

$d_{m}$ - code distance determines the radius of the hyperspherical container of the recognition class $X_{m}^{o}$, which is restored in the radial basis of the binary space of the diagnostic features;

$\delta_{K, i}$ - parameter, which is equal to half of the symmetrical tolerances at the $i$-th diagnostic feature;

$d\left(x_{m} \oplus x_{c}\right)$ - code distance from the $X_{m}^{o}$ class center to the nearest (adjacent) $X_{c}^{o}$ class center;

$\delta_{H, i}$-normed (working) tolerance at the $i$-th diagnostic feature, which defines the parameter $\delta_{K, i}$ domain;

$E_{m}^{(k)}$ - information criterion for optimization of machine learning parameters, which is calculated at the $k$-th step of machine learning;
$\bar{\delta}_{K}$ - quasi-optimal parameter of the control tolerances for the diagnostic features;

$G_{\delta}$ - tolerance range $\delta_{K}$ parameter of the control tolerances for the diagnostic features;

$G_{E}$ - working (admissible) function domain of the information criterion;

$\{k\}$ - a set of steps in machine learning;

$G_{\delta, i}$ - tolerance range of the $\delta_{K, i}$ parameter of the control tolerances for the $i$-th diagnostic feature;

$L$ - the number of the sequential optimization procedure runs for the diagnostic features;

$\otimes$ - character of the repeat operation;

$\alpha_{m}(d)$ - error of the first kind when making classification decisions. It is calculated in the process of restoration of a hyperspherical container of the recognition class $X_{m}^{o}$ with radius $d$;

$\beta_{m}(d)$ - error of the second kind when making classification decisions. It is calculated in the process of restoration of a hyperspherical container of the recognition class $X_{m}^{o}$ with radius $d$;

$10^{-r}$ - sufficiently small number, which is entered to avoid dividing by zero $(1<r \leq 3)$; 
$\delta_{K, i}^{*}$ - optimal value of the control tolerance parameter;

$\rho_{m}-$ selection level of the coordinates of the averaged binary vector-implementation of the recognition class;

$A_{K H, i}[k]$ - lower control tolerance for $i$-th diagnostic feature;

$A_{K B, i}[k]$ - upper control tolerance for $i$-th diagnostic feature;

$y_{1, i}$ - the selective mean value of the $i$-th feature of the averaged vector-implementation of the base class $X_{1}^{o}$;

$E_{m}^{*}(d)$ - the maximum value of the information criterion for optimizing the parameters of machine learning of the functional control system to recognize the implementation of the class $X_{m}^{o}$;

$G_{E}$ - working (admissible) domain of the function information criterion of optimization of machine learning parameters;

$G_{d}$ - tolerance range of geometric parameters of container classes of recognition;

$X_{1}^{o}$ - the base recognition class, for which a system of control tolerances for diagnostic features is determined;

$d_{m}^{*}$ - optimal radius of the recognition class container $X_{m}^{o}$

$x_{c}$ - binary averaged vector of the nearest neighbor class $X_{c}^{o}$;

$x^{(j)}$ - vector-implementation, which can be recognized;

$\mu_{m}$ - the implementation function that is recognizable to the hyperspherical container of the recognition $X_{m}^{o}$ class.

\section{INTRODUCTION}

The requirements for functional efficiency and safety of the hoisting mine machine have been significantly increased with the development of deep deposits of minerals, which is a modern trend in the mining industry. In this, the reliability of the HMM considerably depends on the functionality of its electric drive, the output of which from a given technological regime leads to material losses and even man-made accidents. Therefore, organization of the continuous functional diagnostics of the electric drive and its units becomes of great importance. At the same time the use of traditional methods does not provide high reliability and efficiency of the functional diagnostics because of the multidimensionality of diagnostic features and the intersection of functional states of the HMM.

One of the promising ways to increase the functional efficiency of an automated management system of the HMM is to provide it with an intelligent component based on machine learning and image recognition. Thus, the objective of the study is to develop a computer-aided learning algorithm for the system of functional diagnostics of the HMM within the IEI-technology of data analysis, which is based on maximizing the information capacity of the system in the process of its learning.

\section{PROBLEM STATEMENT}

Consider the formalized statement of the information synthesis of the functional diagnostics system of the HMM electric drive. Let the fuzzy alphabet of recognition classes be given in the general case $\left\{X_{m}^{o} \mid m=\overline{1, M}\right\}$, and each of them characterizes the functional state of units of the electric drive. An educational matrix of the "object-property" type is formed for the given alphabet $\left\|y_{m, i}^{(j)} \mid i=\overline{1, N} ; j=\overline{1, n}\right\|$. In addition, a structured vector of parameters that influences the functional efficiency of machine learning of the system of functional diagnostics is given:

$$
g_{m}=<x_{m}, d_{m}, \delta_{K, i}>,
$$

In addition, the restrictions have been set:

$$
\begin{gathered}
d_{m} \in\left[0 ; d\left(x_{m} \oplus x_{c}\right)-1\right], \\
\left.\delta_{K, i} \in\left[0 ; \delta_{H, i} / 2\right)\right] .
\end{gathered}
$$

While machine learning it is necessary to:

1) optimize parameters of the vector (1) by the average information criterion

$$
\bar{E}=\frac{1}{M} \sum_{m=1}^{M} \max _{E} \cap G_{d}(d) .
$$

2) set decisive rules according to the obtained during the process of machine learning optimal geometry parameters of the containers recognition classes that will guarantee a high probability of making the correct diagnostic decisions.

During the exam, that is, directly in the operational mode of the functional diagnostics, it is necessary to make a classification decision about the affiliation of the current $x^{(j)}$ vector to one of the recognition classes from a given alphabet.

\section{REVIEW OF THE LITERATURE}

Modern systems and methods for diagnosing the electric drive are divided into two groups [1]. The first group includes methods of test diagnostics, which measure the insulation resistance, leakage currents, the internal resistance of the windings, the tangent angle of the dielectric losses of the windings, etc. Disadvantages of the test diagnostics are the temporary cessation of the operation of the electric motor, the lack of the ability to outage the equipment during operation to prevent its complete failure, lack of control of equipment operating modes, etc.

The second group includes methods of functional diagnostics of the electric drive [2,3]. Functional diagnostics of the HMM electric drive refers to the socalled poorly formalized processes. It has to do with reasons reasons such as arbitrary initial conditions due primarily to deviations of the lift load from the calculated one, and the intersection of recognition classes due to the ambiguity of the diagnostic features to the functional states. The analysis of modern approaches and methods of functional diagnostics of electromechanical equipment has shown that in order to increase the accuracy and reliability of its work, 
it is necessary to use intelligent data analysis technologies $[3,4]$. In this, existing methods of intellectual functional diagnosis are based mainly on artificial neural networks [5-7]. The main disadvantage of most known methods of Data Mining technology, including artificial and immune networks, is for their sensitivity to the multidimensionality of the dictionary of diagnostic features and the alphabet of recognition classes. Solving this problem is especially important for functional diagnostics, which in practice needs large volumes of data to be analyzed. In [8] the use of fuzzy methods of control and control of electric drive is considered. It should be noted that the use of fuzzy methods of presentation and withdrawal of new knowledge in the analysis of data is justified in applying a qualitative measurement scale.

One of the most promising ways of analysis and synthesis of the functional diagnostics systems capable to learn is the use of ideas and methods of the so-called IEI-technology, which is based on maximizing the information capability of the system in the process of machine learning $[9,10]$. In [11] within the framework of IEI-technology the task of functional diagnostics of a spinon electric drive was considered. At the same time information-extreme machine learning was carried out at a given optimal in the informational sense of the system of control tolerances for diagnostic features, which did not allow to obtain high functional efficiency of machine learning diagnostic system.

The article deals with the informationally extreme algorithm of machine learning of the functional diagnostic system of HMM electric drive with parallel-sequential optimization of control tolerances for diagnostic features.

\section{MATERIALS AND METHODS}

The idea of machine learning within the IEI-technology is the transition from the Euclidean to binary space recognition features, where the adaptation of the working binary training matrix to the maximum information ability of the system to recognize the multidimensional vectors of the images implementation is carried out by admissible transformations. In this, the main goal of machine learning to create highly reliable decisive rules is achieved at each step by restoring the training of optimal classes of recognition classes upon the information criterion (2). It is the construction of the decisive rules within the geometric approach which makes them practically not sensitive to the multidimensional diagnostic space and allows evaluating the current functional state of the equipment in real time.

Let's consider the informationally-extreme algorithm of machine learning of the system of functional diagnostics with a hyperspherical classifier, in which reconstruction of classes recognition containers occurs by the parallelsequential optimization of the system of control tolerances for diagnostic features. In this, the two-cyclic procedure of the parallel optimization of control tolerances for diagnostic features, in which control tolerances are changed simultaneously at each step of machine learning for all features, is initially implemented:

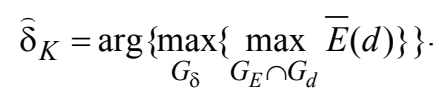

Quasi-optimal control tolerances for diagnostic features, which have been obtained based on the results of parallel optimization, are considered as initial for sequential optimization. This approach allows increasing both the reliability of decision-making and the efficiency of the algorithm of consistent optimization, since the search for the global maximum of the information criterion does not go beyond the boundaries of the function domain. Sequential optimization of the control tolerances for recognition features in the process of machine learning is carried out in accordance with the procedure of approximation of the information optimization criterion global maximum (2) to the limit value in the interval on which a function is defined:

$$
\delta_{K, i}^{*}=\arg \underset{l=1}{\otimes}\left\{\max _{G_{\delta i}}\left[\frac{1}{M} \sum_{m=1}^{M} \max _{E m} \cap G_{d} E_{m}^{(l)}\left(d_{m}\right)\right]\right\}, i=\overline{1, N} .
$$

Consider the main stages of implementation of the informationextreme learning algorithm of functional control system of the hoisting mine machine drive with parallel-sequential optimization of control tolerances for diagnostic features.

An algorithm (3) for machine learning with parallel optimization of control tolerances is initially implemented. The input data is an array of input training matrix for a given alphabet of recognition classes and a parameter of normalized tolerances field based on the scale of diagnostic features. The main stages of implementing the algorithm:

1) zeroing of the recognition class meter: $m:=0$;

2) increment of the recognition class meter: $m:=m+1$;

3) resetting of the amend steps counter of the tolerance field parameter to zero: $k:=0$.

4) increment of the amend steps counter of the tolerance field parameter: $k:=k+1$.

5) resetting of the amend steps counter of the container radius class: $d:=0$

6) increment of the amend steps counter of the container radius class: $d:=d+1$;

7) calculation of the lower $A_{K H, i}[k]$ and upper $A_{K B, i}[k]$ control tolerances for all diagnostic features, according to the formulas

$$
A_{K H, i}[k]=y_{1, i}-\delta[k] \frac{\delta_{H i}}{100} ; A_{K B, i}[k]=y_{1, i}+\delta[k] \frac{\delta_{H i}}{100},
$$

8) the formation of a binary training matrix $\left\|x_{m, i}^{(j)}\right\|$ by the rule

$$
x_{m, i}^{(j)}=\left\{\begin{array}{l}
1, \text { if } A_{K H, i} \leq y_{m, i}^{(j)} \leq A_{K B, i} \\
0, \text { if else }
\end{array}\right.
$$

9) calculation of the binary averaged vector $x_{m}$ for $X_{m}^{o}$ class by the rule

$$
x_{m, i}=\left\{\begin{array}{l}
1, \text { if } \frac{1}{n} \sum_{j=1}^{n} x_{m, i}^{(j)}>\rho_{m} \\
0, \text { if else, }
\end{array}\right.
$$


where the level of selection of the averaged binary vectorrealization coordinates of the $X_{m}^{o}$ class recognition by default is equal to $\rho_{m}=0,5$;

10) pairwise partition of the recognition classes averaged vectors set by the nearest-neighbors method;

11) formation of the training matrix for the pair partition element $\mathfrak{R}_{m}^{|2|}=<x_{m}, x_{c}>$;

12) calculation of the information criterion for optimization of the functional diagnostics system learning parameters, for example, in the form of modification of the information measure of Kulbak [6]

$$
E_{m}(d)=\left\{1-\left[\alpha(d)+\beta_{m}(d)\right]\right\} \log _{2}\left(\frac{2-\left(\alpha_{m}(d)+\beta_{m}(d)\right)+10^{-r}}{\alpha_{m}(d)+\beta_{m}(d)+10^{-r}}\right)
$$

13) if $d<d\left(x_{m} \oplus x_{c}\right)$, then 6 is fulfilled, otherwise point 14;

14) if $k<\delta_{H} / 2$, then 4 is fulfilled, otherwise - point 15

15 ) if $m \leq M$, then 2 is fulfilled, otherwise - point 16 ;

16) calculation of the information optimization criterion (5) of machine learning parameters that is averaged across the alphabet of recognition classes;

17) calculation of the quasi-optimal parameter $\widehat{\delta}$ by the formula (3);

18) calculation of quasi-optimal lower and upper control tolerances for diagnostic features by the formulas (5), respectively:

$$
\widehat{A}_{H K, i}=y_{1, i}^{*}-\widehat{\delta} \frac{\delta_{H i}}{100}, \quad \hat{A}_{B K, i}=y_{1, i}^{*}+\widehat{\delta} \frac{\delta_{H i}}{100} .
$$

19) STOP.

The input data for the algorithm (4) of the sequential optimization of the control tolerances for the diagnostic features is the binary working training matrix that is formed according to the rule (6) for quasi-optimal control tolerances $\left\{\hat{A}_{H K, i} \mid i=1, N\right\},\left\{\hat{A}_{B K, i} \mid i=1, N\right\}$, which were obtained at the parallel optimization stage and the normalized tolerances $\left\{\delta_{H, i}\right\}$ for the diagnostic features. There is a difference between the implementation of the algorithm (4) and the parallel optimization. It is in sequential determination of the optimal control tolerances for each diagnostic feature. But since the optimal control for the $i$-th feature is determined by non-optimal control tolerances for other diagnostic features, then according to the algorithm (4) several sequences of sequential optimization are carried out until the maximum averaged value of the information criterion remains constant. Thus, the process of learning of the functional diagnostics system is in implementation of the procedure for finding the global maximum of the information criterion function in the working area of its definition and iterative approximation of this maximum to its maximum limit value to construct highly reliable rules.

\section{EXPERIMENTS}

The implementation of the discussed above algorithm has been carried out on the basis of machine learning of the HMM electric drive functional diagnostics system. The training matrix was formed with the help of "ULYS Systems", which is involved in the design, production and maintenance of products for mine equipment, based on archival data of DTEK Pavlogradvugillia, mine "Heroes of Space", town of Pavlograd. Each line of the training matrix consisted of 51 structured quantitative and categorical diagnostic features that characterized the electrical and temperature characteristics of the nodes on the technological cycles of the HMM. For clarity, diagnostics was carried out for three classes of recognition: class $X_{1}^{O}$ described the functional state of the electric drive "Norma" and this class was accepted as the basic one, in relation to which the system of control tolerances was determined. Class $X_{3}^{o}$ described high temperatures of the electric motor bearings, and class $X_{3}^{o}$ described high temperatures of the engine winding.

Initially, algorithm (3) of the informationa-extreme machine learning for the system of functional diagnostics of the HMM electric drive with parallel optimization of diagnostic features was implemented, in which control tolerances for all features changed simultaneously at each step of the training. To improve the functional efficiency of machine learning, the algorithm for the sequential optimization of control tolerances for diagnostic features was implemented. In this, the results obtained by parallel optimization control tolerances for diagnostic features were considered as the starting point for their consistent optimization. In this, the results obtained by parallel optimization control tolerances for diagnostic features were considered as the starting point for their consistent optimization. Decisive rules were formulated according to the optimal geometric parameters of the hyperspherical containers of recognition classes obtained in the process of informationally-extreme machine learning. Their predicative expression is given by

$$
\begin{gathered}
\left(\forall X_{m}^{o} \in \mathfrak{R}^{|M|}\right)\left(x^{(j)} \in \mathfrak{R}^{|M|}\right)\left\{\text { if } \left[( \mu _ { m } > 0 ) \& \left(\mu_{m}=\right.\right.\right. \\
\left.=\max _{\{m\}}\left\{\mu_{m} \mid m=\overline{1, M\}}\right] \text { then } x^{(j)} \in X_{m}^{o}\right\} .
\end{gathered}
$$

In expression (8), for example, the membership function of the implementation vector to the hyperspherical container of the recognition class, is determined from the formula

$$
\mu_{m}=1-\frac{d\left(x^{(j)} \oplus x_{m}\right)}{d_{m}^{*}} .
$$

Thus, the recognized implementation vector refers to the recognition class from the given alphabet, for which the membership function (9) is maximum.

\section{RESULTS}

Fig. 1 shows the graph of the information criterion averaged in alphabetical order of the recognition classes (7) versus control tolerances for diagnostic features, which was obtained in the process of diagnostic optimization of the HMM electric drive units according to the algorithm of parallel optimization. 
In fig. 1 the shaded area denotes the working (admissible) domain of the function (7), in which the first and the second authenticity exceeds the errors of the first and the second kind respectively.

Figure 2 shows the dynamics of changes in the maximum values of the information criterion averaged in alphabetical order of the recognition classes (7) when carrying out the procedure of the sequential optimization of the control tolerances for the diagnostic features.

Fig. 3 shows the graphs of the information criterion (7) versus the containers radii of recognition classes, constructed based on the results of parallel-sequential optimization of the optimal control tolerances for diagnostic features.

On the results of the functional diagnostic in test mode, that is the actual testing, probability of the right recognition

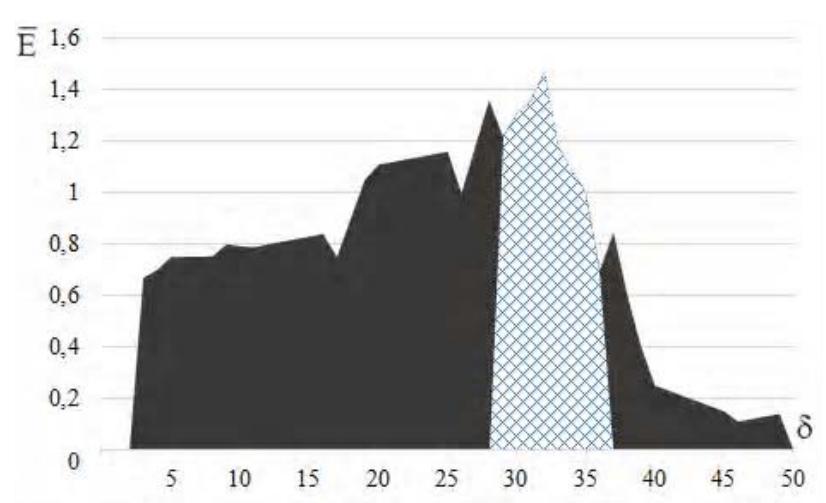

Figure 1 - The graph of information optimization criterion versus parameter of the control tolerances

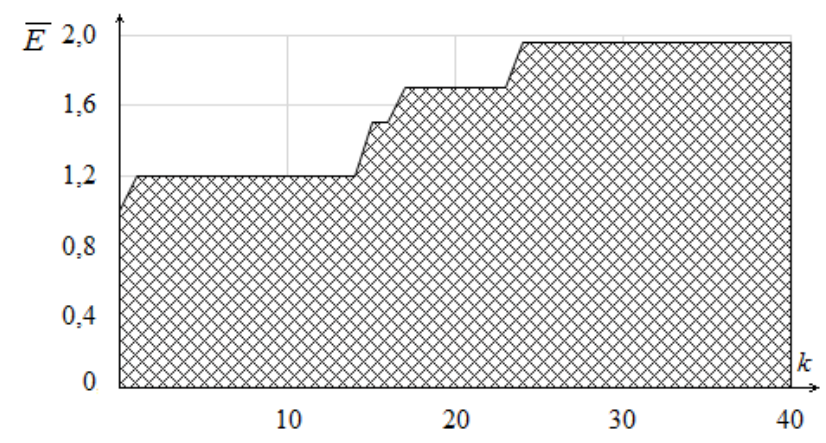

Figure 2 - The graph of maximum information criterion changes from the number of iterations of the sequential optimization of the control tolerances for the diagnostic features of the implementation vectors for class $X_{1}^{O}$ equals $P_{t}=0.94$, for class $X_{2}^{0}$ equals $P_{t}=0.92$ and for class $X_{3}^{0}$ equals $P_{t}=0.89$.

\section{DISCUSSION}

Analysis of Fig. 1 shows that optimal control tolerances parameter is $\delta^{*}= \pm 32$ of relative units at the maximum of the information criterion averaged in alphabetical order of the recognition classes (7) $\bar{E}_{\max }=1.44$, which was obtained in the working domain of the function.

To improve the functional efficiency of machine learning, an algorithm for the sequential optimization of control tolerances for diagnostic features was implemented. In this, the results obtained by parallel optimization control tolerances for diagnostic features were considered as the starting point for their consistent optimization. Sequential optimization of control tolerances for diagnostic signs was carried out according to the procedure (4). Since the number of iterations in a single run of procedure (4) is determined by the number of diagnostic features, the analysis of Fig. 2 shows that already at the first run, the maximum value of the information optimization criterion $\bar{E}^{*}=1.96$, which is substantially higher than its value obtained by the parallel optimization of the control tolerances for the diagnostic features (Fig. 1), was reached.

In order to construct highly reliable decisive rules of type (8) in the machine learning process with optimal control tolerances for diagnostic features, it is necessary to determine the optimal geometric parameters of the containers of recognition classes. Analysis of Fig, 3 shows that optimal radius of the $X_{1}^{O}$ class container equals $d_{1}^{*}=36$ (here and after in code units), for class $X_{2}^{0}-$ $d_{2}^{*}=37$ and for class $X_{3}^{0}-d_{3}^{*}=33$.

It should be noted that the use of constructed geometric approaches to geometric decisive rules significantly reduces the impact of the diagnostic features dictionary multidimensionality and the alphabet of recognition classes on the functional efficiency of machine learning. In this case, there is no need to retrain the system or change its structure as in the application of artificial neural networks. In addition, the construction of decisive rules in the framework of the geometric approach allows to take diagnostic solutions in real time, which is an important condition for functional diagnosis.
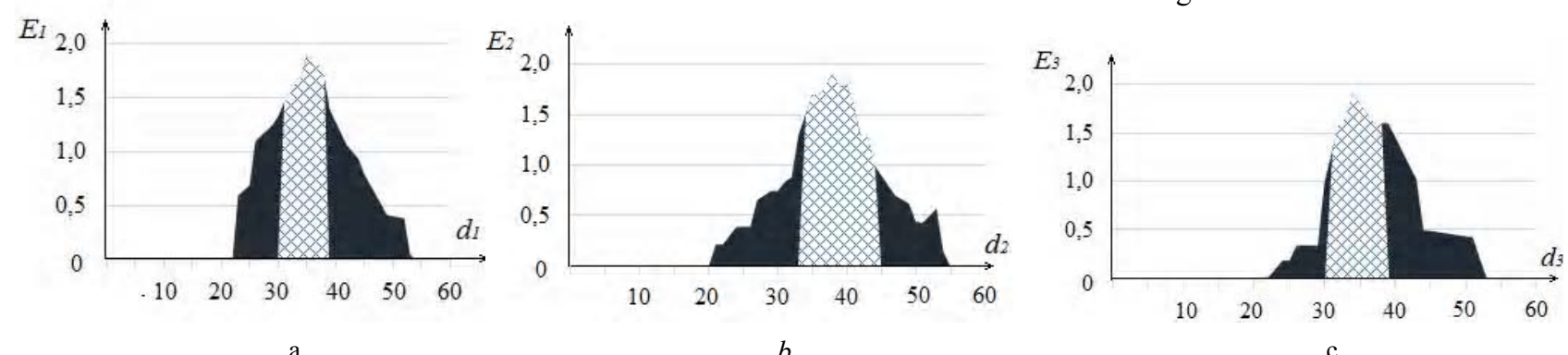

Figure 3 - Graphs of the information criterion (7) versus the containers radii of recognition classes:

$$
a \text { - class } X_{1}^{0} ; b \text { - class } X_{2}^{0} ; c-\text { class } X_{3}^{0}
$$




\section{CONCLUSION}

The important scientific and technical task of increasing the functional efficiency of machine learning of the functional diagnostics system of the HMM electric drive is solved.

The scientific novelty of the results obtained is in the development of a new informationally-extreme method of machine learning of the system of the HMM electric drive functional diagnostics with parallel-sequential optimization of control tolerances for diagnostic features of recognition, which allows to formulate high-confidence decisive rules. In this, unlike artificial neural networks, the use of geometric decisive rules formulated within the framework of a geometric approach significantly reduces the influence of the multidimensional diagnostic features dictionary and the alphabet of recognition classes on the functional efficiency of machine learning. In addition, parallel-consecutive optimization of control tolerances for diagnostic recognition features can significantly improve the efficiency of machine learning, since consistent optimization of control tolerances occurs in the working domain of the function information criterion for optimization of machine learning parameters.

Application of the results obtained allows making decisions on the current technical state of the HMM electric drive, to provide timely repair and replacement of its unreliable nodes and to accumulate archival data for solving the problem of predictive diagnosis for planning preventive measures to restore the functional efficiency of the HMM automated control system.

The decisive rules constructed on the results of machine learning are not accurate according to the training matrix. Further studies need to be carried out in order to deepen machine learning by optimizing other spatio-temporal parameters that affect system functional efficiency of the functional diagnostics in further research according to the principle of delayed solutions for making decisive rules accurate on the training matrix.

\section{REFERENCES}

1. Сидельников Л. Г. Обзор методов контроля технического состояния асинхронных двигателей в процессе эксплуатации / Л. Г. Сидельников, Д. О. Афанасьев // Вестник ПНИПУ. Геология. Нефтегазовое и горное дело. - 2013. - № 7. - С. 127 137.
2. Bhowmik P. S. Faultdiagnostic and monitoring methods of inductionmotor: a review / S. Pradhan,. M. Prakash // International Journal of Applied Control, Electrical and Electronics. - 2013. Vol. 1, № 1. - P. 1-18.

3. Szymacski Z. Intelligent, Energy Saving Power Supply and Control System of Hoisting Mine Machine with Compact and Hybrid Drive System / Szymacski Z., Ukiady Zasilania I Sterowania Gyrniczych Maszyn Wycioogowych Z Nаркdem Zintegrowanym Lub Hybrydowym // Archives of Mining Sciences. Retrieved 3 Mar. 2018. - 60 (1). - P. 239-251. DOI:10.1515/amsc-2015-0016

4. Сидоренко В. Н., Мониторинг мощных электроприводов на основе технологии data mining / В. Н. Сидоренко, А. П. Черный // Электротехнические и компьютерные системы. - 2011. - №3.C. 414-416.

5. Subbotin S. The neuro-fuzzy network synthesis and simplification on precedents in problems of diagnosis and pattern recognition / S. Subbotin // Optical Memory and Neural Networks (Information Optics). - 2013. - Vol. 22, № 2. - P. 97-103. DOI: 10.3103/ s1060992x13020082

6. Petr Dolezel Pattern recognition neural network as a tool for pest birds detection / Petr Dolezel, Pavel Skrabanek, Lumir Gago // Computational Intelligence (SSCIIEEE Symposium Series on). 2016. - P. 1-6. DOI: 10.1109/HSI.2008.4581457

7. Ching-Lien Huang, Tsung-Shin Hsu, Chih-Ming Liu. The Mahalanobis-Taguchi system - Neural network algorithm for datamining in dynamic environments. Expert Systems with Applications / Ching-Lien Huang, Tsung-Shin Hsu, Chih-Ming Liu // An International Journal. - 2009. - Vol. 36, Issue 3. P. 5475-5480. DOI: 10.1016/j.eswa.2008.06.120

8. Hasan A. Yousef, Manal Wahba A. Adaptive fuzzy mimo control of induction motors. Expert Systems with Applications / Hasan A. Yousef, Manal Wahba A. // An International Journal. - 2009. Vol. 36, Issue 3. - P. 4171-4175. DOI 10.1016/j.eswa.2008.04.004

9. Dovbysh A. S., Budnyk M. M., Moskalenko V. V. InformationExtreme Algorithm for Optimizing Parameters of Hyperellipsoidal Containers of Recognition Classes / A. S. Dovbysh, M. M. Budnyk, V. V. Moskalenko // Journal of automation and information sciences. - New York : Begell House Inc., 2012, v. 44. i. 10. - P. 35-44. DOI: 10.1615/ JAutomatInfScien.v44.i10.30

10.Dovbysh A. S. Information-Extreme Method for Classification of Observations with Categorical Attributes / A. S. Dovbysh, V. V. Moskalenko, A. S. Rizhova // Cibernetica and Systems Analysis. 2016. -Vol. 52, No. 2. - P. 45-52. DOI: 10.1007/s10559-0169818-1

11. Зимовець В. І. Система функціонального контролю приводу шахтної підйомної машини, що здатна навчатися / В. І. Зимовець, А. С. Чирва, О. І. Марищенко // Журнал інженерних наук. - 2016. - № 2. - С. 15-19.

Article was submitted 10.04.2018 After revision 25.04.2018.

Довбиш А. С. ${ }^{1}$, Великодний Д. В. ${ }^{2}$, Проценко О. Б. ${ }^{3}$, Зимовець В. I. ${ }^{4}$

'Д-р техн. наук, професор, завідувач кафедри комп'ютерних наук Сумського державного університету, Суми, Україна

${ }^{2}$ Канд. фіз.-мат. наук, завідувач секції кафедри комп'ютерних наук Сумського державного університету, Суми, Україна ${ }^{3}$ Канд. фіз.-мат. наук, доцент, доцент кафедри комп'ютерних наук Сумського державного університету, Суми, Україна ${ }_{4}^{4}$ Аспірант кафедри комп'ютерних наук Сумського державного університету, Суми, Україна

ОПТИМІЗАЦІЯ ПАРАМЕТРІВ МАШИННОГО НАВЧАННЯ СИСТЕМИ ФУНКЦІОНАЛЬНОГО ДІАГНОСТУВАННЯ ЕЛЕКТРОПРИВОДУ ШАХТНОЇ ПІДЙОМНОЇ МАШИНИ

Актуальність. Розв'язана актуальна задача підвищення функціональної ефективності машинного навчання системи функціонального діагностування електроприводу шахтної підйомної машини.

Мета роботи - розробка методу інформаційного синтезу здатної навчатися системи функціонального діагностування електроприводу шахтної підйомної машини, який дозволяє за побудованими в процесі машинного навчання вирішальними правилами підвищити достовірність та оперативність діагностичних рішень.

Метод. Запропоновано метод інформаційно-екстремального машинного навчання системи функціонального діагностування електроприводу шахтної підйомної машини, що грунтується на максимізації інформаційної спроможності системи в процесі ії навчання. За отриманими в результаті машинного навчання оптимальними в інформаційному розумінні параметрами гіперсферичних контейнерів класів розпізнавання побудовано в рамках геометричного підходу вирішальні правила, практично інваріантні до багатовимірності простору діагностичних ознак. Крім того, підвищення оперативності машинного навчання системи досягається шляхом паралельнопослідовної оптимізації контрольних допусків на діагностичні ознаки. При цьому отримані в процесі паралельної оптимізації квазіоп- 
тимальні контрольні допуски на діагностичні ознаки використовуються як стартові при їх послідовній оптимізації. Як критерій оптимізації параметрів машинного навчання використовується модифікована інформаційна міра Кульбака, яка є функціоналом від точнісних характеристик діагностичних рішень.

Результати. Розроблено алгоритмічне та програмне забезпечення машинного навчання системи функціонального діагностування електроприводу шахтної підйомної машини, яке дозволяє побудувати вирішальні правила для прийняття високо достовірних діагностичних рішень при функціонуванні системи в робочому режимі

Висновки. За результатами фізичного моделювання підтверджено працездатність запропонованого методу машинного навчання і розробленого програмного забезпечення системи функціонального діагностування електроприводу шахтної підйомної машини, що дозволяє їх рекомендувати для розв'язання практичних задач діагностування і автоматичного керування тяговими машинами.

Ключові слова: інформаційно-екстремальна інтелектуальна технологія, функціональне діагностування, машинне навчання, інформаційний критерій, електропривод, шахтна підйомна машина.

Довбыш А. С. ${ }^{1}$, Великодный Д. В. ${ }^{2}$, Проценко Е. Б. ${ }^{3}$, Зимовец В. И. ${ }^{4}$

Д-р техн. наук, профессор, заведующий кафедрой компьютерных наук Сумского государственного университета, Сумы, Украина

${ }^{2}$ Канд. физ.-мат.наук, заведующий секции кафедры компьютерных наук Сумского государственного университета, Сумы, Украина

${ }^{3}$ Канд. физ.-мат.наук, доцент, доцент кафедры компьютерных наук Сумского государственногоуниверситета, Сумы, Украина

${ }^{4}$ Аспирант кафедры компьютерных наук Сумского государственного университета, Сумы, Украина

ОПТИМИЗАЦИЯ ПАРАМЕТРОВ МАШИННОГО ОБУЧЕНИЯ СИСТЕМЫ ФУНКЦИОНАЛЬНОГО ДИАГНОСТИРОВАНИЯ ЭЛЕКТРОПРИВОДА ШАХТНОЙ ПОДЬЕМНОЙ МАШИНЫ

Актуальность. Решена актуальная задача повышения функциональной эффективности машинного обучения системы функционального диагностирования электропривода шахтной подъемной машины.

Цель работы - разработка метода информационного синтеза обучающейся системы функционального диагностирования электропривода шахтной подъемной машины, позволяющего по построенным в процессе машинного обучения решающим правилам повысить достоверность и оперативность диагностических решений.

Метод. Предложено метод информационно-экстремального машинного обучения системы функционального диагностирования электропривода шахтной подъемной машины, основанный на максимизации информационной способности системы в процессе ее обучения. По полученным в результате машинного обучения оптимальным в информационном смысле параметрам гиперсферических контейнеров классов распознавания построены в рамках геометрического подхода решающие правила, практически инвариантные к могомерности пространства диагностических признаков. Кроме того, повышение оперативности машинного обучения системы достигается путем параллельно-последовательной оптимизации контрольных допусков на диагностические признаки. При этом полученные в процессе параллельной оптимизации квазиоптимальные контрольные допуски на диагностические признаки используются в качестве стартовых при их последовательной оптимизации. В качестве критерия оптимизации параметров машинного обучения используется модифицированная информационная мера Кульбака, являющаяся функционалом от точностных характеристик диагностических решений.

Результаты. Разработано алгоритмическое и программное обеспечение машинного обучения системы функционального диагностирования электропривода шахтной подъемной машины, позволяющее построить решающие правила для принятия высокодостоверных диагностических решений при функционировании системы в рабочем режиме.

Выводы. Результаты физического моделирования подтверджают работоспособность предложенного метода машинного обучения и разработанного программного обеспечения системы функционального диагностирования электропривода шахтной подъемной машины, что позволяет их рекомендовать для решения практических задач диагностирования и автоматического управления тяговыми машинами.

Ключевые слова: информационно-экстремальная интеллектуальная технология, функциональное диагностирование, машинное обучение, информационный критерий, электропривод, шахтная подъемная машина.

\section{REFERENCES}

1. Sidel'nikov L.G. Obzor metodov kontrolya tekhnicheskogo sostoyaniya asinkhronnykh dvigateley v protsesse ekspluatatsii, Vestnik PNIPU, Geologiya. Neftegazovoe i gornoe delo, 2013, No. 7, pp. 127-137.

2. Bhowmik P. S., Pradhan S., Prakash M. Faultdiagnostic and monitoring methods of inductionmotor: a review, International Journal of Applied Control, Electrical and Electronics, 2013, Vol. 1, pp. 1-18.

3. Szymacski, Z., Ukiady Zasilania I Sterowania Gyrniczych Maszyn WyciNogowych Z Napкdem Zintegrowanym Lub Hybrydowym Intelligent, Energy Saving Power Supply and Control System of Hoisting Mine Machine with Compact and Hybrid Drive System. Archives of Mining Sciences, 60(1), pp. 239-251. Retrieved 3 Mar. 2018. DOI:10.1515/amsc-2015-0016

4. Sidorenko V. N., Cherniy A. P. Monitoring moshchnykh elektroprivodov na osnove tekhnologii data, Elektrotekhnicheskie $i$ komp'yuternye sistemy, 2011, No. 3, pp. 414-416.

5. Subbotin S. The neuro-fuzzy network synthesis and simplification on precedents in problems of diagnosis and pattern recognition, Optical Memory and Neural Networks (Information Optics), 2013, Vol. 22, No. 2, pp. 97-103. DOI:: 10.3103/s1060992x13020082

6. Petr Dolezel, Pavel Skrabanek, Lumir Gago Pattern recognition neural network as a tool for pest birds detection, Computational
Intelligence (SSCIIEEE Symposium Series on), 2016, pp. 1-6. DOI: 10.1109/HSI.2008.4581457

7. Ching-Lien Huang, Tsung-Shin Hsu, Chih-Ming Liu. The Mahalanobis-Taguchi system - Neural network algorithm for data-mining in dynamic environments. Expert Systems with Applications, An International Journal, 2009, Vol. 36, Issue 3, pp. 5475-5480. DOI: 10.1016/j.eswa.2008.06.120

8. Hasan A. Yousef, Manal Wahba A. Adaptive fuzzy mimo control of induction motors. Expert Systems with Applications, $A n$ International Journal, 2009, Vol. 36, Issue 3, pp. 4171-4175. DOI: 10.1016/j.eswa.2008.04.004

9. Dovbysh A. S., Budnyk M. M., Moskalenko V. V. InformationExtreme Algorithm for Optimizing Parameters of Hyperellipsoidal Containers of Recognition Classes, Journal of automation and information sciences. New York, Begell House Inc., 2012, v. 44. i. 10. pp. 35-44. DOI: 10.1615/ JAutomatInfScien.v44.i10.30

10. Dovbysh A. S., Moskalenko V. V., Rizhova A. S. InformationExtreme Method for Classification of Observations with Categorical Attributes, Cibernetica and Systems Analysis, 2016, Vol. 52, No. 2, pp. 45-52. DOI: 10.1007/s10559-016-9818-1

11. Zimovec' V. I., Chirva A. S., Marishhenko O. I. Sistema funkcional'nogo kontrolju privodu shahtnoï pidjomnoï mashini, zdatna navchatisja, Zhurnal inzhenernih nauk, 2016, No. 2, pp. $15-19$. 